\title{
ECOLOGICAL ALTERNATIVES FOR DISEASE MANAGEMENT OF FRUIT ROT PATHOGENS
}

\author{
K.R. EVERETT ${ }^{1}$, J.L. VANNESTE ${ }^{2}$, I.C. HALLETT ${ }^{1}$ and M. WALTER ${ }^{3}$ \\ ${ }^{1}$ HortResearch, Private Bag 92169, Mt Albert, Auckland, New Zealand \\ ${ }^{2}$ HortResearch,Private Bag 3123, Hamilton, New Zealand \\ ${ }^{3}$ HortResearch, P.O. Box 51, Lincoln, New Zealand
}

Corresponding author: Keverett@hortresearch.co.nz

\begin{abstract}
Biological control of plant pathogens utilises one micro-organism to eliminate or reduce the disease caused by another. Inundative biological control utilises naturally-occurring microbial antagonists (biological control agents) that are isolated and reapplied in large numbers to suppress disease. This strategy has been studied for over 40 years and a number of commercial products for fruit rot control have been developed. Recent advances in techniques for monitoring microbial population dynamics, such as denaturing gradient gel electrophoresis (DGGE), microarrays, fluorescent in situ hybridisation (FISH) and the polymerase chain reaction (PCR), have made it easier to study an alternative strategy, restorative biological control. This aims to stimulate resident populations of biological control agents (BCAs) using benign interventions that do not harm microorganisms. The use of these techniques is reviewed, and their advantages and disadvantages are compared. The relevance of these techniques to the development of restorative biological control and future research to lead to improved disease management of fruit rots are discussed.
\end{abstract}

Keywords: restorative biological control, DGGE, arrays, BCA.

\section{INTRODUCTION}

Biological control of plant pathogens has been defined as "the use of one or more organisms (agents) to maintain another organism (pest) at a level at which it is no longer a problem". In 1995, two types of biological control were recognised. The first is classical: "the release of a coevolved fungal pathogen into an exotic environment where the target pest is an alien or non-indigenous species". The second is inundative, defined as "the application of a mass-produced, typically necrotrophic fungus as a mycopesticide" (Hawkesworth et al. 1995). Bacteria and yeasts have also been utilised as biological control agents (Baker \& Cook 1974). There have been several examples of commercialised BCA products for fruit disease as an outcome from research in inundative biological control. Botry-zen ${ }^{\circledR}$ (Anon 2005) is an example of a fungus utilised to control botrytis in grapes. Bacterial BCAs such as Serenade ${ }^{\mathrm{TM}}$ (Bacillus subtilis) (Walton et al. 2002) are registered for control of grape botrytis and powdery mildew, and Blossom Bless $^{\circledR}$ (Pantoea agglomerans) (Vanneste et al. 2002) for control of fire blight (Erwinia amylovora), a bacterial disease of pears and apples.

Inundative biological control of fruit disease and mechanisms for this control are briefly discussed in this review as well as improvements that have lead to a new development in this field, termed restorative biological control. The means for this change are evaluated, firstly by improvement of inundative control through addition of nutritional supplements and other additives, and secondly with the development of new tools for tracking changes in microbial populations. The aim of restorative biological control is to stimulate resident populations of biological control agents (BCAs) using benign interventions that do not harm micro-organisms. Future directions for this research approach are discussed. 
The focus is on the study of fruit rots, and use of these methods in related areas of research as well as studies of the phylloplane is reviewed. Studies of the phylloplane (leaf surface) are relevant to fruit rots, and this term is used as a synonym for fructoplane (fruit surface) for clarity.

\section{INUNDATIVE BIOLOGICAL CONTROL}

Inundative biological control of plant disease has been investigated for more than 40 years (McSpadden-Gardener \& Fravel 2002). Various mechanisms for disease control by BCAs have been described, including production of antibiotics (Levy \& Carmeli 1995) or lytic enzymes (Fogliano et al. 2002), competition for nutrients (Kredics et al. 2004) and/or niche (Droby et al. 2002), hyperparasitism (Huang 1992), hypovirulence (Milgroom \& Cortesi 2004), elicitation of natural defence mechanisms in the host, such as induced resistance (van Loon et al. 1998) and cross protection (Valkonen et al. 2002). Another mode of action of some microbial agents is the modification of the chemical environment resulting in allelopathic biocontrol (Rice 1994). For example, the breakdown of organic matter in the soil releases antimicrobial compounds such as phenolics (Yedidia et al. 2003) or compounds that enhance the chelation of nutrients such as iron that are essential for pathogen development (Manwar et al. 2000).

The population of the biological control agent applied inundatively is initially higher than is usually found in nature and commonly declines over time. If it reaches a level at which it no longer controls disease a further application is required. The rate of population decline is often related to environmental factors that cannot be controlled, and is thus unpredictable. In some products, improved survival of the BCAs in the field has been achieved by formulating them with various compounds, including a patentable polymer (Townsend et al. 2004). Despite their obvious limitations, BCAs are commercially available demonstrating the usefulness of this method of disease control.

\section{ADDITION OF BENIGN SUPPLEMENTS}

The addition of nutritional supplements in combination with BCAs has been reported to improve disease control. This improvement in control may be the result of improved growth of the BCA, stimulation of host defence mechanisms, inhibition of the pathogen by the supplement, or a combination of these and other factors. The first experiment to improve biological control following the addition of nutrients was carried out by Bhatt \& Vaughn (1962) who used fungal biocontrol agents against Botrytis cinerea in strawberry. There have been many reports since of similar successful experiments, including the use of Chaetomium globosum in a formulation containing cellulose to manage apple diseases (Davis et al. 1992).

The potential of nutrient supplements to enhance the biocontrol efficacy of yeasts and bacteria has also been studied. For example, addition of glycolchitosan to Candida saitoana enhanced control of grey and blue mould of apple caused by Botrytis cinerea and Penicillium expansum compared with $C$. saitoana or glycolchitosan applied alone (El-Ghaouth et al. 2000). Nunes et al. (2001) found that addition of the chemicals ammonium molybdate and calcium chloride allowed Candida sake to be applied at lower concentrations to achieve control against blue mould on apples and pears. Further discussion of chemical enhancement of biocontrol is provided by Reglinski et al. (2005). Guetsky et al. (2002) found that addition of amino acids, vitamins and other nutritional supplements gave improved suppression of $B$. cinerea by Pichia guilermondii on detached strawberry leaflets. The biocontrol activity of the bacterium, Bacillus cereus, against early leafspot of peanut was improved by adding chitin with the biocontrol agent (Kokalis-Burelle et al. 1992).

\section{NEW TOOLS FOR TRACKING CHANGES IN MICROBIAL POPULATIONS}

Traditional methods, such as dilution plating, limit the number of samples that can be analysed and are recognised as being inadequate for microbial population studies 
(Brock et al. 1987). However, a number of tools have recently been developed that can be used for tracking changes in overall microbial populations or in populations of specific genera, species or pathovars. These more rapid and less labour-intensive methods should allow for the study of various treatments, including the effects of a greater number of benign interventions on disease organisms, under field conditions. The techniques include numerous variants of the polymerase chain reaction (PCR), fluorescent in situ hybridisation (FISH), hybridisation assays such as dot-blots and arrays, cell flow cytometry, and community fingerprinting techniques, such as amplified ribosomal DNA restriction analysis (ARDRA) and denaturing gradient gel electrophoresis (DGGE). Each of these techniques has advantages and disadvantages when compared to standard dilution plating and microscopical technology (Table 1). Due to the concise nature of this paper, the focus on discussion of these techniques will be on their use. For more extensive reviews of these techniques, references are provided in Table 1.

TABLE 1: Important features of some techniques for microbial ecology studies.

\begin{tabular}{|c|c|c|c|c|c|c|}
\hline Technique & $\begin{array}{l}\text { Cell } \\
\text { viability }\end{array}$ & Quantifiable & $\begin{array}{l}\text { Community } \\
\text { profiling }\end{array}$ & $\begin{array}{l}\text { Species } \\
\text { identification }\end{array}$ & Labour & Reviews \\
\hline $\begin{array}{l}\text { Dilution } \\
\text { plating }\end{array}$ & Yes & Yes & Yes & Possible & High & Brock 1987 \\
\hline Microscopy & Yes & Yes & No & Possible & Very high & Drahos 1991 \\
\hline $\mathrm{PCR}^{1}$ & $\begin{array}{l}\text { Not } \\
\text { usually }\end{array}$ & Possible & No & Yes & Low & $\begin{array}{l}\text { Hollomon } \\
2003\end{array}$ \\
\hline $\mathrm{FISH}^{2}$ & Yes & Yes & No & Yes & Moderate & $\begin{array}{l}\text { Tay et al. } \\
2001\end{array}$ \\
\hline $\begin{array}{l}\text { Flow } \\
\text { cytometry }\end{array}$ & Yes & Yes & No & No & Low & $\begin{array}{l}\text { Ivanov et al. } \\
2004\end{array}$ \\
\hline ARDRA $^{3}$ & No & No & Yes & Possible & Low & $\begin{array}{l}\text { Smit et al. } \\
1997\end{array}$ \\
\hline DGGE $^{4}$ & No & Partial & Yes & Possible & Moderate & $\begin{array}{l}\text { O'Callaghan } \\
\text { et al. } 2003\end{array}$ \\
\hline Arrays & No & Yes & Possible & Yes & Low & $\begin{array}{l}\text { Tiquia et al. } \\
2004\end{array}$ \\
\hline
\end{tabular}

${ }^{1} \mathrm{PCR}=$ Polymerase chain reaction.

${ }^{2} \mathrm{FISH}=$ fluorescent in situ hybridisation.

${ }^{3} \mathrm{ARDRA}=$ amplified ribosomal DNA restriction analysis.

${ }^{4} \mathrm{DGGE}=$ denaturing gradient gel electrophoresis.

To date there are very few reports on the use of these techniques for studying microbial ecology on the phylloplane. Most studies are concerned with identification and detection of plant pathogens, studying genetic variability or studying populations in liquid environments or soil. For instance, arrays have been used to identify and detect various pathogens from soil, irrigation water and plant tissue for tomato vascular wilt pathogens (Lievens et al. 2003), and bacterial pathogens of potato from plant tissue (Fessehaie et al. 2003). PCR of intertranscribed spacer (ITS) regions of ribosomal DNA followed by enzyme digest (ARDRA) was used by Jeng et al. (2001) to detect and differentiate the pathogenic bacterium, Erwinia amylovora, from common orchard epiphytes. Pruvost \& Gagnevin (2002) summarise the use of a range of different DNA technologies to study populations of Xanthomonas species, but these tools are designed to study genetic variability rather than to quantify population fluctuations. DGGE was used by Yang et al. (2001) to show that microbial populations of the phylloplane were more complex than previously realised by analysing genetic diversity. Green et al. (2004) showed that genetic diversity identified by DGGE was a useful technique for demonstrating relatedness between different isolates of Colletotrichum. Several species 
of Fusarium infecting asparagus were discriminated by DGGE analysis (Yergeau et al. 2005) utilising their genetic variability. DGGE was also used to study organism diversity in wastewater (Kreuzinger et al. 2003) and in soil (Milling et al. 2004). Array technology has been used to quantify microbial population fluctuations within intestinal (Daly \& Shirazi-Beechey 2003) and aquatic ecosystems (Steward et al. 2004). FISH and cell flow cytometry methods were used in tandem to identify population fluctuations of viable bacteria in sewage sludge and food waste (Ivanov et al. 2004).

Of relevance to the study of microbial populations of the phylloplane, is work by Mengoni et al. (2003) where ARDRA was used to monitor population fluctuations of endophytic bacteria and phytoplasmas in elm trees. It was shown that trees affected by phytoplasmas had less extensive endophytic bacterial population fluctuations compared with uninfected trees. DGGE was used by Sigler et al. (2005) to show that repeated application of a BCA to irrigation water resulted in transient displacement of a leaf surface bacterial community member.

\section{RESTORATIVE BIOLOGICAL CONTROL}

It is not surprising that addition of nutritional supplements in combination with BCAs enhances biological control, as leaf surfaces are typically a nutrient-limited environment. Bacteria in the phyllosphere are primarily carbon-limited and secondarily nitrogen-limited (Wilson \& Lindow 1994, 1995; Wilson et al. 1995). The amendment of nutrient status of the phylloplane with selective carbon sources could be employed to increase the population size and efficacy of a BCA in the phyllosphere, and thus control disease, if the primary mechanism of the BCA was population size dependent (Wilson et al. 1995). More recently, Morris \& Kinkel (2002) postulate that further information on the dynamics of the genetic and phenotypic diversity on the phylloplane will be critical to the development of enhanced disease management strategies. These studies are now possible because of the development of several new techniques (Table 1). The combination of these factors has lead to a new disease management strategy termed restorative biological control.

This strategy can be defined as encouraging population growth of resident microflora to cause a reduction in disease incidence. It provides an alternative to repeated application of BCAs to the phylloplane by stimulating resident populations of BCAs using benign interventions. Currently there are no commercial products resulting from this concept, and very few publications on this subject.

\section{THE FUTURE}

Future research strategies for restorative biological control are required to adopt new technologies to the specific requirements of this research. In particular, DGGE, arrays, and FISH in combination with traditional techniques show the most potential for tracking microbial population changes on the phyllosphere. The challenge for both DGGE and arrays is to identify those organisms that are suitable indicators of change in microbial populations useful for disease management. An integral part of this research is to identify new BCAs. Another challenge for arrays is to develop methods for quantifying microbial populations on the phylloplane. Once these challenges have been overcome, restorative biological control research needs to focus on screening likely nutritional candidates for benign interventions. Two intermediate outcomes of this research will be increased knowledge of the interactions between micro-organisms on the phylloplane following benign interventions, and identification of new BCAs. The ultimate goal is to manage disease by enhancing populations of resident beneficial micro-organisms using benign supplements that do no harm.

\section{ACKNOWLEDGEMENTS}

This review was written as part of FRST Contract No. CO6X0302. 


\section{REFERENCES}

Anon. 2005. Botry-zen ${ }^{\circledR}$ Limited. http://www.botryzen.co.nz (Accessed 2 June 2005). Baker KF, Cook RJ 1974. Biological control of plant pathogens. WH Freeman, San Francisco, USA.

Bhatt DD, Vaughn EK 1962. Preliminary investigations on biological control of gray mold (Botrytis cinerea) of strawberries. Plant Disease Reporter 46: 342-345.

Brock TD 1987. The study of microorganisms in situ: Progress and problems. In: Fletcher M, Gray TRG, Jones JG ed. Ecology of Microbial Communities. Cambridge University Press, Cambridge, UK. Pp. 1-17.

Daly K, Shirazi-Beechey SP 2003. Design and evaluation of group-specific oligonucleotide probes for quantitative analysis of intestinal ecosystems: their application to assessment of equine colonic microflora. FEMS Microbiology Ecology 44: 243-252.

Davis RF, Backman PA, Rodrigez-Kabana R, Kokalis-Burelle N 1992. Biological control of apple fruit diseases by Chaetomium globosum formulations containing cellulose. Biological Control 2:118-123.

Drahos DJ 1991. Methods for the detection, identification, and enumeration of microbes. In: Andrews JH, Hirano SS ed. Microbial ecology of leaves. Springer-Verlag, New York, USA. Pp. 135-157.

Droby S, Vinokur V, Weiss B, Cohen L, Daus A, Goldschmidt EE, Porat R 2002. Induction of resistance to Penicillium digitatum in grapefruit by the yeast biocontrol agent Candida oleophila. Phytopathology 92: 393-399.

El-Ghaouth A, Smilanick JL, Wilson CL 2000. Enhancement of the performance of Candida saitoana by the addition of glycolchitosan for the control of postharvest decay of apple and citrus fruit. Postharvest biology and Technology 19: 103-110.

Fessehaie A, De Boer SH, Levesque CA 2003. An oligonucleotide array for the identification and differentiation of bacteria pathogenic on potato. Phytopathology 93: 262-269.

Fogliano V, Ballio A, Gallo M, Wu S, Scala F, Lorito M 2002. Pseudomonas lipepsipeptides and fungal cell wall-degrading enzymes act synergistically in biological control. Molecular Plant Microbe Interactions 15: 323-333.

Green SJ, Freeman S, Hadar Y, Minz D 2004. Molecular tools for isolate and community studies of Pyrenomycete fungi. Mycologia 96: 439-451.

Guetsky R, Elad Y, Shtienberg D, Dinoor A 2002. Improved Biocontrol of Botrytis cinerea on detached strawberry leaves by adding nutritional supplements to a mixture of Pichia guilermondii and Bacillus mycoides. Biocontrol Science and Technology 12: 625-630.

Hawkesworth DL, Kirk PM, Sutton BC, Pegler DN 1995. Ainsworth \& Bisby's Dictionary of the Fungi. 8th ed. CAB International, Wallingford, UK.

Hollomon D 2003. Applying modern diagnostics to plant disease control. Annual Review of Plant Pathology 2: 287-297.

Huang HC 1992. Ecological basis of biological control of soilborne plant pathogens. Canadian Journal of Plant Pathology 14: 86-91.

Ivanov VN, Wang JY, Stbnikova OV, Tay STL, Tay JH 2004. Microbiological monitoring in the biodegradation of sewage sludge and food waste. Journal of Applied Microbiology 96: 641-647.

Jeng RS, Svircev AM, Myers AL, Beliaeva L, Hunter DM, Hubbes M 2001. The use of $16 \mathrm{~S}$ and $16 \mathrm{~S}-23 \mathrm{SrDNA}$ to easily detect and differentiate common Gram-negative orchard epiphytes. Journal of Microbiological Methods 44: 69-77.

Kokalis-Burelle N, Backman PA, Rodriguez-Kabana R, Ploper LD 1992. Potential for biological control of early leafspot of peanut using Bacillus cereus and chitin as foliar amendments. Biological Control 2: 321-328. 
Kredics L, Manczinger L, Antal Z, Penzes Z, Szekeres A, Kevei F, Nagy E 2004. In vitro water activity and $\mathrm{pH}$ dependence of mycelial growth and extracellular enzyme activities of Trichoderma strains with biocontrol potential. Journal of Applied Microbiology 96: 491-498.

Kreuzinger N, Farnleitner A, Wandl G, Hornek R, Mach R 2003. Molecular biological methods (DGGE) as a tool to investigate nitrification inhibition in wastewater treatment. Water Science and Technology 47: 165-172.

Levy E, Carmeli S 1995. Biological control of plant pathogens by antibiotic-producing bacteria. In: Inderjit-Dakshini KMM, Einhellig, FA. ed. Allelopathy: organisms, processes and applications. American Chemical Society, Washington, USA. Pp. 300-309.

Lievens B, Brouwer M, Vanachter ACRC, Levesque CA, Cammue BPA, Thomma BPHJ 2003. Design and development of a DNA array for rapid detection and identification of multiple tomato vascular wilt pathogens. FEMS Microbiology Letters 223: 113-122.

Manwar AV, Vaiganker PD, Bhonge LS, Chincholkar SB 2000. In vitro suppression of plant pathogens by siderophores of fluorescent pseudomonads. Indian Journal of Microbiology 40: 109-112.

McSpadden Gardener BB, Fravel DR 2002. Biological control of plant pathogens: Research, Commercialization, and application in the USA. http://www.apsnet. org/online/feature/biocontrol

Mengoni A, Mocali S, Surico G, Tegli S, Fani R 2003. Fluctuation of endophytic bacteria and phytoplasmosis in elm trees. Microbiological Research 158: 363-369.

Milgroom MG, Cortesi P 2004. Biological control of chestnut blight with hypovirulence: a critical analysis. Annual Review of Phytopathology 42: 311-338.

Milling A, Smalla K, Maidl FX, Schloter M, Munch JC 2004. Effects of transgenic potatoes with an altered starch composition on the diversity of soil and rhizosphere bacteria and fungi. Plant and Soil 266: 23-39.

Morris CE, Kinkel LL 2002. Fifty years of phyllosphere microbiology: significant contributions to research in related fields. In: Lindow SE, Hecht-Poinar EI, Elliott VJ ed. Phyllosphere Microbiology. The American Phytopathological Society, St. Paul, USA. Pp. 365-375.

Nunes C, Usall J, Teixido N, Miro M, Vinas I 2001. Nutritional enhancement of bicontrol activity of Canidida sake (CPA-1) against Penicillium expansum on apples and pears. European Journal of Plant Pathology 107: 543-551.

O'Callaghan M, Gerard EM, Heilig GHJ, Zhang H, Jackson TA, Glare TR 2003. Denaturing gradient gel electrophoresis- a tool for plant protection research. New Zealand Plant Protection 56: 143-150.

Pruvost O, Gagnevin L 2002. Population structure of Xanthomonads with endophytic and pegiphytic phases: the example of the pathovar mangeraeindicae/mango pathosystem. In: Lindow SE, Hecht-Poinar EI, Elliott VJ ed. Phyllosphere Microbiology. The American Phytopathological Society, St. Paul, USA. Pp. 209224.

Reglinski T, Elmer PAG, Taylor JT, Parry FJ, Marsden R, Wood PN 2005. Suppression of Botrytis bunch rot in Chardonnay grapevines by induction of host resistance and fungal antagonism. Australasian Plant Pathology 34(4): in press.

Rice EL 1994. Biological control of selected plant diseases by microorganisms. Allelopathy Journal 1: 77-88.

Sigler WV, Nakatsu CH, Reicher ZJ, Turco RF 2005. Fate of the biological control agent Pseudomonas aureofaciens TX-1 after application to turfgrass. Applied and Environmental Microbiology 67: 3542-3548.

Smit E, Leeflang P, Wernars K 1997. Detection of shifts in microbial community structure and diversity in soil caused by copper contamination using amplified ribosomal DNA restriction analysis. FEMS Microbiology Ecology 23: 249-261. 
Steward GF, Jenkins BD, Ward BB, Zehr JP 2004. Development and testing of a DNA macroarray to assess nitrogenase (nifH) gene diversity. Applied and Environmental Microbiology 70: 1455-1465.

Tay STL, Ivanov V, Kim IS, Feng L, Tay J-H 2001. Quantification of ratios of Bacteria and Archaea in methanogenic microbial community by fluorescence in situ hybridization and fluorescence spectrometry. World Journal of Microbiology and Biotechnology 17: 583-589.

Tiquia SM, Chong SC, Fields MW, Zhou JZ 2004. Oligonucleotide based functional gene arrays for analysis of microbial communities in the environment. In: Kowalchuk GA, de Bruijn FJ, Head IM, Akkermans ADL, van Elsas JD ed. Molecular microbial ecology manual Volumes 1 and 2. 2nd ed. Kluwer Academic, Dordrecht, Netherlands. Pp. 1743-1761.

Townsend TJ, Ferguson CM, Proffitt JR, Slay MWA, Swaminathan J, Day S, Gerard E, O'Callaghan M, Johnson VW, Jackson TA 2004. Establishment of Serratia entomophila after application of a new formulation for grass grub control. New Zealand Plant Protection 57: 310-313.

Valkonen JPT, Rajamaki ML, Kekarainen T 2002. Mapping of viral genomic regions important in cross-protection between strains of a Potyvirus. Molecular Plant Microbe Interactions 15: 683-692.

van Loon LC, Bakker PAHM, Pieterse CMJ 1998. Systemic resistance induced by rhizosphere bacteria. Annual Review of Phytopathology 36: 453-483.

Vanneste JL, Cornish DA, Yu J, Voyle MD 2002. P10c: a new biological control agent for control of fire blight which can be sprayed or distributed using honey bees. Acta Horticulturae 590: 231-235.

Walton D ed. 2002. New Zealand Agrichemical Manual. WHAM Media Limited, Wellington, New Zealand.

Wilson M, Lindow SE 1994. Coexistence among epiphytic bacterial populations mediated through nutritional resource partitioning. Applied and Environmental Microbiology 60: 4468-4477.

Wilson M, Lindow SE 1995. Enhanced epiphytic coexistence of near-isogenic salicylatecatabolizing and non-salicylate-catabolizing Pseudomonas putida strains after exogenous salicylate application. Applied and Environmental Microbiology 61: 1073-1076.

Wilson M, Savka MA, Hwang I, Farrand SK, Lidow SE 1995. Altered epiphytic colonization of mannityl opine-producing transgenic tobacco plants by a mannityl opine-catabolizing strain of Pseudomonas syringae. Applied and Environmental Microbiology 61: 2151-2158.

Yang CH, Crowley DE, Borneman J, Keen NT 2001. Microbial phyllosphere populations are more complex than previously realized. Proceedings of the National Academy of Science of the United States of America 98: 3889-3894.

Yedidia I, Shoresh M, Kerem Z, Benhamou N, Kapulnik Y, Chet I 2003. Concomitant induction of systemic resistance to Pseudomonas syringae pv. lachrymans in cucumber by Trichoderma asperellum (T-203) and accumulation of phytoalexins. Applied and Environmental Microbiology 69: 7343-7353.

Yergeau E, Filion M, Vujanovic V, St Arnaud M 2005. A PCR-denaturing gradient gel electrophoresis approach to assess Fusarium diversity in asparagus. Journal of Microbiological Methods 60: 143-154. 